\title{
FAKTOR-FAKTOR YANG MEMPENGARUHI PENERAPAN KETERLIBATAN KARYAWAN PADA INDUSTRI MANUFAKTURING
}

\author{
Alden Nelson ${ }^{1)}$, \\ Fakultas Ekonomi, Universitas Internasional Batam, \\ Sei Ladi J1 Gajah Mada, Baloi Batam 29442 \\ email: aldenn2007@gmail.com \\ Agustinus Setyawan ${ }^{2)}$ \\ Fakultas Ekonomi, Universitas Internasional Batam, \\ Sei Ladi Jl Gajah Mada, Baloi Batam 29442 \\ email: setyawan.agustinus@gmail.com
}

\begin{abstract}
The research conducted to discuss the factors that affecting the implementation of employee engagement. Employee engagement contributes to companies where low turnover, high profitability and high productivity. The results of the study explained the direct effect that leadership, teamwork, management support had a significant effect to employee motivation and employee development / training, environment / workplace, teamwork, management support, employee motivation directly influencing to employee engagement but performance management, compensation / remuneration leadership does not have a significant effect to employee engagement.

Indirect influence explains that leadership and team work have a significant effect to employee engagement through employee motivation but management support does not significantly influence employee engagement through employee motivation.
\end{abstract}

Keywords: Leadership, Team Work, Management Support, Employee Development / Training, Performance Assessment, Compensation / Remuneration, Environment / Workplace, Employee Motivation and Employee Engagement.

\begin{abstract}
ABSTRAK
Penelitian dilakukan untuk membahas faktor-faktor yang mempengaruhi penerapan keterlibatan karyawan. Analisis statistik deskriptif yang digunakan adalah SEM (Structural Equation Modeling) Smart PLS (Partial Least Squares) 3.0 professional. Hasil analisis menjelaskan tentang pengaruh langsung dimana kepemimpinan, kerjasama tim, dukungan menejemen berpengaruh signifikan terhadap motivasi karyawan. Pengembangan/pelatihan karyawan, lingkungan/ tempat kerja, kerjasama tim, dukungan menejemen, motivasi karyawan berpengaruh signifikan terhadap keterlibatan karyawan tetapi penilaian kinerja, kompensasi/ remunirasi, kepemimpinan tidak berpengaruh signifikan terhadap keterlibatan karyawan. Pengaruh tidak langsung menjelaskan bahwa kepemimpinan dan kerjasama tim berpengaruh signifikan terhadap keterlibatan karyawan melalui motivasi karyawan tetapi dukungan menejemen tidak berpengaruh signifikan terhadap keterlibatan karyawan melalui motivasi karyawan.
\end{abstract}

Kata Kunci: Kepemimpinan, Kerjasama Tim, Dukungan Manejemen, Pengembangan/ Pelatihan Karyawan, Penilaian Kinerja, Kompensasi/ remunirasi, Lingkungan/ Tempat Kerja, Motivasi Karyawan dan Keterlibatan Karyawan. 


\section{PENDAHULUAN}

Kompetisi berdemensi global memberikan dampak dimana setiap perusahaan harus mampu berkompetisi sehingga ketika perusahaan tidak mampu melakukan persaingan di era globalisasi maka perusahaan bisa mengalami kerugian bahkan tidak beroperasi. Oleh karena itu kinerja perusahaan harus ditingkatkan sehingga perusahaan tetap dapat bertahan serta dapat mengatasi persaingan global dengan meningkatkan keterlibatan karyawan (Neha, 2011).

Pengamatan yang dilakukan oleh Gallup (2013) terhadap karyawan yang terlibat memberikan kontribusi dimana keinginan karyawan berpindah kerja (turnover) yang rendah, profitabilitas tinggi, produktivitas tinggi, dan rendah ketidakhadiran (absenteeism). Aon Hewitt (2015) menyampaikan bahwa peningkatkan pendapatan perusahaan sebesar 3 persen terjadi karena peningkatan 5 persen dari keterlibatan karyawan. Sebaliknya, karyawan yang tidak terlibat mempengaruhi perusahaan mereka dengan cara lain kontribusi mereka yang terbatas ke tempat kerja (Blessing White, 2013; Muthuveloo et al. 2013).

Laporan secara global tentang keterlibatan menunjukkan bahwa hanya sekitar 30 persen karyawan terlibat dalam pekerjaan mereka (Gallup, 2013). Sekitar 32.000 peserta mengungkapkan bahwa hanya empat yang keluar dari sepuluh karyawan di seluruh dunia sangat terlibat; 24 persen dilepas, 36 persen tidak didukung atau terpisah dan 60 persen tidak memiliki elemen yang diperlukan untuk menjadi terlibat (Tower Watson, 2014). Blessing White (2013) menemukan bahwa sekitar 40, 42, 22, 37, 34 dan 31 persen karyawan di Amerika Utara, India, Cina, Australia / Selandia Baru, Gulf Cooperation Council dan negara-negara Eropa terlibat dalam pekerjaan mereka masing-masing. CIPD (2015) baru-baru ini melakukan survei tentang keterlibatan kerja 2.226 karyawan di seluruh industri yang berbeda di pasar menemukan bahwa hanya sekitar 39 persen dari karyawan terlibat aktif.

Keterlibatan karyawan merupakan fenomena menarik dalam perusahaan khususnya dalam bidang sumberdaya manusia. Telah banyak penelitian dan teori yang mengatakan bahwa seorang karyawan yang mempunyai rasa keterlibatan yang tinggi adalah kunci kesuksesan perusahaannya. Banyak penelitian baik di bidang manajemen maupun psikologi menyataan bahwa hal ini disebabkan karena individu yang sepenuhnya terlibat dan antusias dalam pekerjaannya, akan bertindak dan mengambil keputusan dengan landasan kepentingan perusahaannya. Konsep keterlibatan karyawan yang disampaikan oleh Kahn (1990) merupakan pemanfaatan dari anggota perusahaan agar mereka dapat berperan penuh dalam perusahaan tersebut. Hal lain yang disampaikan Khan bahwa keterlibatan karyawan berpusat pada pengalaman tentang pekerjaan dan akhirnya terbentuk karyawan yang aktif maupun tidak aktif selama mereka bekerja. Keterikatan yang kuat antara karyawan dan pemimpin dapat meningkatkan ikatan kerja. Keterlibatan karyawan yang semakin tinggi maka akan menimbulkan rasa keterikatan yang tinggi pula dalam suatu perusahaan. Dukungan yang kuat yang dilakukan seorang pemimpin terhadap karyawannya terutama dalam hal komunikasi berdampak pada lebih terikat karyawan dalam pekerjaannya.

Keterlibatan karyawan memiliki dampak signifikan positif bagi perusahaan dalam hal perbaikan produktivitas sehingga memberikan kontribusi terhadap bertambahnya pendapatan bagi perusahaan. Ada banyak faktor sehingga keterlibatan karyawan meningkat dan salah satu faktor yang menentukan keterlibatan karyawan adalah lingkungan kerja yang nyaman bagi karyawan. Hal tersebut memberikan 
arti terhadap dampak sosial yang dilakukan oleh perusahaan. Karyawan akan menikmati banyak manfaat dari lingkungan tempat kerja, tim kerja yang kondusif, kesejahteraan pekerja meningkat dan metode-metode yang dilakukan oleh perusahaan untuk meningkatkan keterlibatan karyawan. Dan pada akhirnya memberikan keuntungan bagi kedua pihak (perusahaan dan karyawan ) Anita (2014).

Gallup (2002) mengemukakan ada tiga golongan karyawan yakni karyawan yang terlibat (engaged), karyawan tidak merasa terlibat (not engaged), dan karyawan yang aktif melepaskan diri (actively disengaged). Karyawan yang terlibat adalah pembangun yang secara konsisten berusaha untuk memberikan keunggulan dalam peran pekerjaannya dan lebih produktif. Karyawan yang tidak merasa terlibat fokus hanya pada pekerjaan yang dijabarkan kepada mereka dari pada tujuan organisasi. Mereka melakukan apa yang diperintahkan dan cenderung kurang optimal. Karyawan yang aktif keluar merupakan individu berbahaya yang tidak memiliki kinerja baik dan mengalami penurunan motivasi dalam pekerjaan.

Oleh karena penjelasan dari latar belakang diatas maka penelitian akan difokuskan pada masalah :

1. Apakah kepemimpinan mempengaruhi motivasi karyawan?

2. Apakah kerjasama tim mempengaruhi motivasi karyawan?

3. Apakah dukungan manajemen mempengaruhi motivasi karyawan?

4. Apakah pengembangan karyawan (pelatihan) mempengaruhi keterlibatan karyawan?

5. Apakah kompensasi (remunirasi) mempengaruhi keterlibatan karyawan?
6. Apakah penilaian kinerja mempengaruhi keterlibatan karyawan?

7. Apakah lingkungan (tempat) kerja mempengaruhi keterlibatan karyawan?

8. Apakah kepemimpinan mempengaruhi keterlibatan karyawan?

9. Apakah kerjasama tim mempengaruhi keterlibatan karyawan?

10. Apakah dukungan manajemen mempengaruhi keterlibatan karyawan?

11. Apakah motivasi karyawan mempengaruhi keterlibatan karyawan?

12. Apakah kepemimpinan mempengaruhi keterlibatan karyawan melalui motivasi karyawan sebagai mediasi?

13. Apakah kerjasama tim mempengaruhi keterlibatan karyawan melalui motivasi karyawan sebagai mediasi?

14. Apakah dukungan manajemen mempengaruhi keterlibatan karyawan melalui motivasi karyawan sebagai mediasi?

Permasalahan penelitian yang telah dijabarkan diatas memiliki tujuan:

1. Untuk menganalisa dampak positif dari kepemimpinan terhadap motivasi karyawan.

2. Untuk menganalisa dampak positif dari kerjasama tim terhadap motivasi karyawan.

3. Untuk menganalisa dampak positif dari dukungan manajemen terhadap motivasi karyawan.

4. Untuk menganalisa dampak positif dari pengembangan karyawan 
(pelatihan) terhadap keterlibatan karyawan.

5. Untuk menganalisa dampak positif dari sistem kompensasi (remunirasi) terhadap keterlibatan karyawan.

6. Untuk menganalisa dampak positif dari penilaian kinerja terhadap keterlibatan karyawan.

7. Untuk menganalisa dampak positif dari lingkungan (tempat) kerja keterlibatan karyawan.

8. Untuk menganalisa dampak positif dari kepemimpinan terhadap keterlibatan karyawan.

9. Untuk menganalisa dampak positif dari kerjasama tim terhadap keterlibatan karyawan.

10. Untuk menganalisa dampak positif dari dukungan manajemen terhadap keterlibatan karyawan.

11. Untuk menganalisa dampak positif dari motivasi karyawan terhadap keterlibatan karyawan.

12. Untuk menganalisa dampak positif dari kepemimpinan terhadap keterlibatan karyawan melalui motivasi karyawan sebagai mediasi.

13. Untuk menganalisa dampak positif dari dukungan manajemen terhadap keterlibatan karyawan melalui motivasi karyawan sebagai mediasi.

14. Untuk menganalisa dampak positif dari dukungan manajemen terhadap keterlibatan karyawan melalui motivasi karyawan sebagai mediasi

\section{Kerangka Teoritis dan Perumusan Hipotesis.}

Penelitian mengenai keterlibatan karyawan (employee engagement) pada awalnya dikembangkan oleh Kahn (1990). Keterlibatan karyawan yang dikembangkan dalam abad ke-20 ternyata masih terus dilakukan sampai abad ke-21. Berdasarkan hasil penelusuran referensi, dalam satu dekade terakhir masih banyak peneliti yang mengkaji keterlibatan karyawan serta masih banyak lagi peneliti yang melakukan penelitian tentang keterlibatan karyawan.

Peneliti yang tertarik melakukan penelitian tentang keterlibatan karyawan bukan hanya dilakukan di satu benua saja, tetapi hampir semua peneliti di seluruh benua tertarik mengkaji keterlibatan karyawan. Ada yang meneliti keterlibatan karyawan di Eropa (Yunani, Finlandia, dan Inggris) dan peneliti di Amerika yang mengkaji keterlibatan karyawan. Peneliti yang melakukan penelitian di Afrika yang melakukan penelitian tentang keterlibatan karyawan dilakukan di Kenya, Ethiophia dan Afrika selatan sedangkan di Asia, para peneliti melakukan penelitian di United Arab Emirates, Mesir dan India dan masih banyak lagi juga mengkaji keterlibatan karyawan. Hal ini menunjukkan isu tentang keterlibatan karyawan masih menjadi isu menarik dalam disiplin ilmu manajemen sumber daya manusia.

\section{Pengaruh Kepemimpinan dan Keterlibatan Karyawan.}

Pendapat Macey dan Schneider, dan Attridge bahwa kepemimpinan merupakan suatu gambaran pola perilaku positif yang tidak berubah-rubah yang diterapkan pada interaksi antara pemimpin dan pengikut, kepemimpinan dianggap penting untuk mempromosikan keterlibatan karyawan. Meski beragam tipologi kepemimpinan telah diidentifikasi (Bass, Drath, Goleman), lalu Zhang, kami mengadopsi teori Avery dimana kepemimpinan dikelompokkan menjadi empat paradigma kepemimpinan: (1) klasik; (2) transaksional; (3) visioner; dan (4) gaya organik.

Dalam kurun waktu 10 tahun terakhir terdapat 21 penelitian yang dipublikasi pada jurnal internasional terindeks yang meneliti pengaruh kepemimpinan terhadap 
keterlibatan karyawan. Untuk kawasan Asia, peneliti-peneliti, antara lain disampaikan Tomlinson (2010), Xu dan Thomas (2011), Hartog dan Belschak (2012), Deemirtas (2013), Anitha (2014), Dajani (2015), Mehrzi dan Singh (2016), Bui, Zeng, dan Higgs (2017) merupakan beberapa peneliti yang mengkaji hubungan antara kepemimpinan dan keterlibatan karyawan. Hasil dari penelitian mengungkapkan bahwa kepemimpinan berpengaruh positif dan signifikan terhadap keterlibatan karyawan. Dengan kata lain semakin baik kemampuan memimpin suatu organisasi maka keterlibatan karyawan terhadap suatu organisasi semakin erat/ kuat.

\section{Pengaruh pengembangan karyawan/ pelatihaan dan ket erlibatan karyawan.}

Pelatihan merupakan hal penting yang dipertimbangkan dalam keterlibatan karyawan dimana pelatihan dapat membantu karyawan dalam menyelesaikan pekerjaannya. Ketika karyawan mengikuti pelatihan maka karyawan tersebut akan memiliki motivasi kuat dalam melakukan keterlibatan dan pekerjaannya (Paradise, 2008). Penelitian yang mengkaji tentang hubungan pengembangan karyawan/ pelatihaan (employee development) training) dan keterlibatan karyawan (employee engagement) telah diteliti antara lain oleh Choo \& Omari (2013), Anitha (2014), Korzynski (2015), Dajani (2015). Peneliti tersebut mengungkapkan adanya pengaruh positif antara pengembangan karyawan (pelatihan) dengan keterlibatan karyawan sedangkan Choo dan Omari (2013) menyatakan bahwa pengembangan karyawan merupakan prediktor yang paling kuat dalam keterlibatan. Hal ini menjelaskan bahwa dengan dilakukannya pengembangan karyawan maka keterlibatan karyawan terhadap organisasi semakin tinggi.

\section{Pengaruh sistem remunirasi/ kompensasi dan keterlibatan karyawan}

Kompensasi merupakan metode dalam suatu organisasi bermanfaat untuk mendapatkan karyawan terbaik. Organisasi harus melakukan penelitian terhadap pasar termasuk industry dari organisai tersebut sehingga paket remunirasi sejalan dengan strategi talenta. Penelitian yang mengkaji tentang hubungan system kompensasi, remunirasi (remuneration /compensation,) dan keterlibatan karyawan (employee engagement) telah diteliti antara lain oleh Kipyegon (2012), Choo dan Omari (2013), Anitha (2014), Dajani (2015). Para peneliti tersebut mengungkapkan adanya pengaruh antara sistem penghargaan karyawan, remunirasi/ kompensasi) dan keterlibatan karyawan (employee engagement). Dari para peneliti tersebut mengatakan bahwa sistem remunirasi/ kompensasi memiliki hubungan signifikan positif khususnya peneliti Kipyegon (2012) mengatakan bahwa remunirasi/ kompensasi merupakan kontributor terbesar terhadap keterlibatan karyawan dan karyawan yang keterlibatan tinggi sangat berpengaruh terhadp keberhasilan organisasi. Dengan kata lain semakin baik sistem remunirasi/ kompensasi di suatu organisasi maka keterlibatan karyawan terhadap suatu organisasi akan semakin tinggi.

\section{Pengaruh lingkungan/ tempat kerja dan keterlibatan karyawan.}

Lingkungan/ tempat kerja terdiri dari rekan kerja, atasan, prosedur kerja, sumber daya lainnya yang mendukung lingkungan kerja dan memiliki dampak pada keselamatan, lingkungan kerja yang berintegrasi kepada keterlibatan karyawan (Shuck, 2010). Karyawan perlu diberikan tempat kerja yang nyaman sehingga memberikan kontribusi dalam pengembangan diri (Schaufeli dan Bakker, 2004). Penelitian yang menguji tentang hubungan lingkungan/ tempat kerja (work environment/ place) dan keterlibatan 
karyawan (employee engagement) telah diteliti antara lain oleh Kipyegon (2012), Anitha (2014), Tkachenko (2014), Rhoades (2016). Para peneliti tersebut mengungkapkan adanya pengaruh antara lingkungan/ tempat kerja (work environment/ place) dan keterlibatan karyawan (employee engagement) dimana peneliti Anitha J., (2014), Rhoades (2016) mengatakan bahwa lingkungan/ tempat kerja memiliki dampak signifikan terhadap keterlibatan karyawan, sementara Tkachenko (2014), Kipyegon (2012) mengatakan bahwa lingkungan/ tempat kerja memiliki korelasi positif terhadap keterlibatan karyawan.

\section{Pengaruh kerjasama tim dan keterlibatan karyawan}

Hubungan dalam kerjasama tim merupakan aspek penting dalam keterlibatan karyawan. Kahn (1990) menemukan bahwa dukungan dan hubungan kepercayaan secara individu yang merupakan kerjasama tim akan mempromosikan keterlibatan karyawan. Penelitian yang menguji tentang kerjasama tim dan keterlibatan karyawan (employee engagement) telah diteliti antara lain oleh Anitha (2014), Murrer (2015), Mehrzi dan Singh, (2016). Para peneliti tersebut mengungkapkan adanya pengaruh antara kerjasama tim (team work) dan keterlibatan karyawan (employee engagement) dimana ke tiga peneliti tersebut mengatakan bahwa tim kerja memiliki dampak signifikan positif secara statistik terhadap keterlibatan karyawan. Dengan kata lain semakin baik kerjasama tim di suatu organisasi maka keterlibatan karyawan terhadap suatu organisasi semakin tinggi.

\section{Pengaruh dukungan manajemen/ organisasi dan keterlibatan karyawan Gillet et al. (2013) menemukan bahwa karyawan yang merasakan}

dukungan dari organisainya, melalui pengakuan dan kewenangan akan memberikan kontribusi pada motivasi pribadi dan keterlibatan karyawan. Penelitian yang menguji tentang dukungan manajemen/organisasi dan keterlibatan karyawan (employee engagement) telah diteliti antara lain oleh Ram dan Prabhakar (2011), Mehrzi dan Singh (2016). Para peneliti tersebut mengungkapkan adanya pengaruh positif antara antara dukungan manajemen/organisasi (management) organization support) dan keterlibatan karyawan (employee engagement) dimana ke dua peneliti tersebut mengatakan bahwa dukungan manajemen/organisasi memiliki dampak signifikan secara statistik terhadap keterlibatan karyawan. Dengan kata lain semakin kuat dukungan manajemen di suatu organisasi maka keterlibatan karyawan terhadap suatu organisasi semakin tinggi.

\section{Pengaruh penilaian/manajemen kinerja dan keterlibatan karyawan}

Dimulainya proses dalam suatu manajemen kinerja dilakukan ketika bergabungnya karyawan baru kedalam sebuah organisasi hingga karyawan tersebut memutuskan untuk tidak bekerja di organisasi . Peningkatan kinerja dari organisasi akan selalu meningkat ketika kinerja secara individu ditingkatkan dalam konteks kerjasama tim. Penelitian yang menguji tentang hubungan penilaian kinerja (performance management) dan keterlibatan karyawan (employee engagement) telah diteliti antara lain oleh Kipyegon (2012) dan Kumar (2012). Para peneliti tersebut mengungkapkan adanya pengaruh signifikan positif antara penilaian kinerja (performance management) dan keterlibatan karyawan (employee engagement). Dengan kata lain sistem penilaian kinerja yang dirancang dengan baik di suatu organisasi maka keterlibatan karyawan terhadap suatu organisasi semakin tinggi. 


\section{Pengaruh motivasi karyawan keterlibatan karyawan}

Motivasi merupakan keinginan dari dalam diri seseorang yang memberikan dorongan untuk melakukan tindakan sehingga mencapai sasaran yang diharapkan Pinder, (1998). Dengan adanya motivasi maka seseorang akan lebih libat dalam suatu kegiatan atau organisasi. Ketika motivasi seseorang hilang maka akan sulit mengharapkan karyawan tersebut terlibat. Penelitian yang menguji tentang motivasi (motivation) dan keterlibatan karyawan (employee engagement) telah diteliti antara lain oleh Mehrzi dan Singh (2016), Ugaddan dan Park (2017). Para peneliti tersebut mengungkapkan adanya pengaruh signifikan (positif) antara motivasi (motivation) dan keterlibatan karyawan (employee engagement).

Pada dasarnya keterlibatan karyawan merupakan fenomena untuk terus diteliti disebabkan keterlibatan karyawan jelas memberikan kontribusi bagi perusahaan. Dengan adanya kontribusi dari karyawan terhadap perusahaan maka akan memberikan kelangsungan bagi karyawan maupun perusahaan.

Model hypothesis yang mempengaruhi keterlibatan karyawan sebagai berikut:

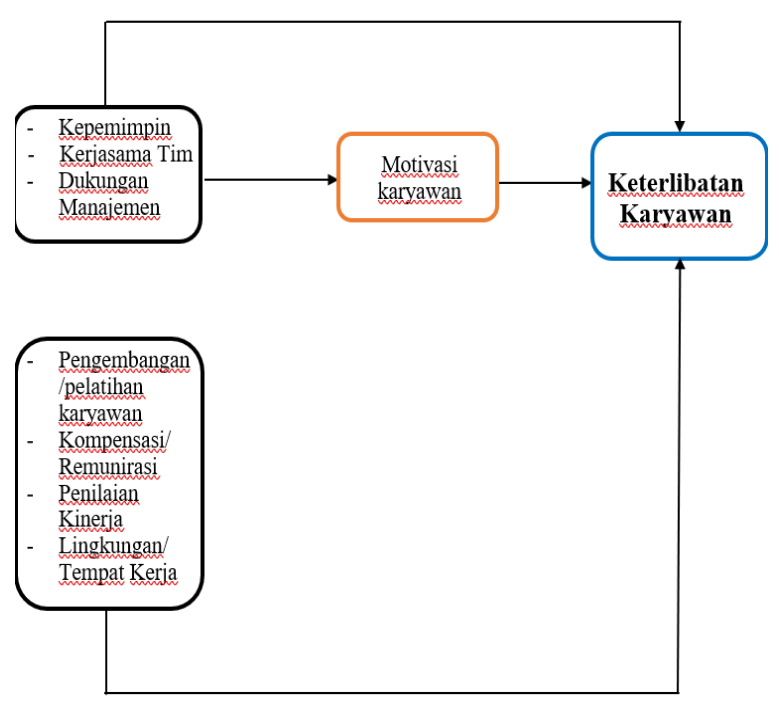

Sesuai dengan data diatas maka variabel-variabel yang akan dipergunakan adalah variabel independent, mediasi dan dependen. Adapun variabel independen yang akan dipakai adalah kepemimpinan, pengembangan karyawan/pelatihan, remunirasi/ kompensasi, kerjasama tim lingkungan/ tempat kerja, dukungan manajemen dan penilaian kinerja sedangkan variabel terikat yang digunakan adalah keterlibatan karyawan. Untuk variabeh penghubung (mediasi) yang digunakan adalah motivasi karyawan.

Dalam mendukung model penelitian yang dijabarkan diatas maka dijabarkan hipotesis dalam melakukan penelitian sebagai berikut:

$\mathrm{H}_{1}$ : Kepemimpinan berpengaruh positif terhadap motivasi karyawan.

$\mathrm{H}_{2}$ : Kerjasama tim berpengaruh positif terhadap motivasi karyawan.

$\mathrm{H}_{3}$ : Dukungan manajemen berpengaruh positif terhadap motivasi karyawan.

$\mathrm{H}_{4}$ : Pengembangan karyawan (pelatihan) berpengaruh positif terhadap keterlibatan karyawan.

$\mathrm{H}_{5}$ : Kompensasi (remunirasi) berpengaruh positif terhadap keterlibatan karyawan. 
$\mathrm{H}_{6}$ : Penilaian/manejemen kinerja berpengaruh positif terhadap keterlibatan karyawan.

$\mathrm{H}_{7}$ : Lingkungan (tempat kerja) berpengaruh positif terhadap keterlibatan karyawan.

H8: Kepemimpinan berpengaruh positif terhadap keterlibatan karyawan.

$\mathrm{H}_{9}$ : Kerjasama tim berpengaruh positif terhadap keterlibatan karyawan.

$\mathrm{H}_{10}$ : Dukungan manajemen berpengaruh positif terhadap keterlibatan karyawan

$\mathrm{H}_{11}$ : Motivasi karyawan berpengaruh positif terhadap keterlibatan karyawan.

$\mathrm{H}_{12}$ : Motivasi karyawan memediasi pengaruh kepemimpinan terhadap keterlibatan karyawan.

$\mathrm{H}_{13}$ : Motivasi karyawan memediasi pengaruh kerjasama tim terhadap keterlibatan karyawan

$\mathrm{H}_{14}$ : Motivasi karyawan memediasi pengaruh dukungan manajemen/ organisasi terhadap keterlibatan karyawan.

\section{MODEL PENELITIAN}

Penelitian yang dilakukan memiliki maksud untuk menguji betapa pentingnya pengaruh antara variabel independen yaitu gaya kepemimpinan, kerjasama team, dukungan manajemen, pengembangan karyawan, sistem kompensasi (remunirasi), lingkungan kerja, dan manajemen kinerja dan variable intervening yaitu motivasi karyawan terhadap variabel dependen yaitu keterlibatan karyawan.

Populasi penelitian dikhususkan pada karyawan yang bekerja pada perusahaan multinational company dimana perusahaan tersebut bergerak dala electronics manufacturing yang ada di Batam.

Penelitian akan dilakukan pada tiga Kawasan industri yang ada di Batam yang bergerak dibidang electronic manufacturing. Jumlah populasi karyawan pada jabatan Supervisor hingga Direktur yang diperoleh sesuai data dari bagian sumber daya manusia dirinci pada Tabel 3.2.1 di bawah ini:

\section{Tabel 1}

Jumlah Populasi di Tiga

Kawasan Industri Batam

\begin{tabular}{|c|l|l|c|}
\hline 1 & \multicolumn{2}{|l|}{$\begin{array}{l}\text { Kawasan Batamindo Industri } \\
\text { Park Muka Kuning }\end{array}$} & 6235 \\
\hline 2 & Kawasan Industri Panbil & 1235 \\
\hline 3 & $\begin{array}{l}\text { Kawasan Industri Cammo } \\
\text { Batam Centre }\end{array}$ & 446 \\
\hline & $\begin{array}{l}\text { Sumber: Divisi HRD } \\
\text { Perusahaan . }\end{array}$ & Total & $\mathbf{7 9 1 6}$ \\
\hline
\end{tabular}

Metode pemilihan sampel yang digunakan adalah stratified random sampling. Teknik ini digunakan bila populasi mempunyai anggota atau unsur yang tidak sejenis dan bertingkat/berstrata (Sugiyono, 2014:123). Sesuai data table yang dibuat oleh Krejcie dan Morgan (1970), maka jumlah minimum sampel (n) yang harus digunakan dalam penelitian ini yakni 364 responden sesuai dengan jumlah karyawan pada tiga kawasan industri tersebut diatas. Hal ini berguna untuk mencegah terjadinya data yang tidak sah pada data kuesioner yang dilakukan pada saat penelitian. Adapun pertanyaan kuesioner yang akan disebarkan dalam survei berjumlah 52 pertanyaan.

Statistik deskriptif merupakan statistik yang digunakan dalam menganalisis data dengan cara menggambarkan data yang telah terkumpul sebagaimana adanya tanpa bermaksud membuat kesimpulan yang berlaku secara umum (Sugiyono, 2014:199). Analisis deskriptif digunakan untuk memberikan informasi mengenai 
karakteristik variabel penelitian (kepemimpinan, kerjasama tim, dukungan manajemen, pengembangan/ pelatihan karyawan, kompensasi/ remunirasi, penilaian kinerja, lingkungan/ tempat kerja, motivasi karyawan dan keterlibatan karyawan) serta penjelasan umum tentang data demografi responden.

\section{Uji Pengaruh Langsung dan Tidak Langsung}

Uji pengaruh antar variabel laten yang bersifat langsung bertujuan untuk mengukur tingkat signifikansi hubungan antar variabel laten tersebut.

Uji pengaruh tidak langsung menjelaskan besarnya pengaruh tidak langsung hubungan suatu variabel eksogen laten terhadap variabel endogen laten lainnya. Juga, mengukur tingkat signifikansi hubungan tersebut. Seperti uji pengaruh langsung, suatu hubungan dikatakan signifikan dengan tingkat signifikansi sebesar 5\% jika memiliki nilai T-Statistics lebih besar dari 1,96 dan P-Values lebih kecil dari 0,05 (Hair et al., 2011).

\section{HASIL DAN PEMBAHASAN}

Kuesioner yang didistribusikan dalam mendukung penelitian berjumlah 430 kuesioner dan data penelitian yang terkumpulkan berjumlah 409 responden diperoleh melalui karyawan manufakturing elektronik di kawasan Cammo Industri, kawasan Panbil, dan kawasan Muka Kuning yang berada di Kota Batam. Data responden yang telah terkumpul diolah mengggunakan Statistical Package for the Social Sciences (SPSS) versi 22 untuk mengetahui karakteristik responden secara umum. Dari data kuisiner yang ada serta dilakukan pengolahan data maka terdapat data outlier sebanyak 13 kuesioner sehingga data kuesioner yang layak diuji dalam melakukan penelitian adalah sebanyak 396 kuesioner.
Responden yang berpartisipasi dalam penelitian adalah pria berjumlah 260 dan wanita berjumlah 149 dengan jabatan dari Supervisor hingga Direktur.

\section{Hasil Uji Common Method Biases (CMB)}

Sebelum melakukan analisis partial least squares (PLS), uji Common Method Biases (CMB) harus dilaksanakan terlebih dahulu dengan metode Harman's Single Factor atau Harman's One Factor Test dan dilakukan melalui program IBM SPSS Statistics 22. Melalui hasil uji CMB maka diperoleh nilai persentase tertinggi dari variance dalam penelitian ini adalah 49.647\%. Data tersebut memberikan arti bahwa dengan nilai kurang dari $50 \%$ yang menunjukkan bahwa tidak ada single factor yang terdapat dalam kuesioner serta menjelaskan bahwa tidak ada variance lebih dari 50\%, dalam kata lain, tidak terjadi common method biases sehingga melalui data yang ada maka dapat dilanjutkan untuk melakukan analisis partial least squares

\section{Hasil Uji Validitas dan Reabilitas}

Uji validitas dilakukan dengan menggunakan Average Variance Extracted ( $A V E$ ) dan memiliki hasil bahwa 9 variabel dinyatakan valid.

\begin{tabular}{|l|c|l|}
\hline \multicolumn{1}{|c|}{ Konstruk/Variabel } & $\begin{array}{c}\text { Sample } \\
\text { Mean } \\
(\mathrm{M})\end{array}$ & Validitas \\
\hline L - Kepemimpinan & 0.690 & Valid \\
\hline WT - Kerjasama Tim & 0.576 & Valid \\
\hline MS - Dukungan & 0.706 & Valid \\
\hline
\end{tabular}




\begin{tabular}{|l|c|l|} 
Menejemen & & \\
\hline $\begin{array}{l}\text { TD - Pengembangan } \\
\text { /pelatihan karyawan }\end{array}$ & 0.634 & Valid \\
\hline PM - Penilaian kinerja & 0.852 & Valid \\
\hline $\begin{array}{l}\text { CR - Kompensasi/ } \\
\text { remunirasi }\end{array}$ & 0.660 & Valid \\
\hline $\begin{array}{l}\text { WE - Lingkungan/ } \\
\text { tempat Kerja }\end{array}$ & 0.620 & Valid \\
\hline $\begin{array}{l}\text { M - Motivasi } \\
\text { karyawan }\end{array}$ & 0.793 & Valid \\
\hline
\end{tabular}

Uji reliabilitas dilakukan dengan menggunakan Composite Reliability dan memiliki hasil bahwa 9 variabel dinyatakan reliabel.

\begin{tabular}{|l|c|c|}
\hline Konstruk/Variabel & $\begin{array}{l}\text { Sample } \\
\text { Mean } \\
(\mathrm{M})\end{array}$ & Reliabilitas \\
\hline L - Kepemimpinan & 0.899 & Reliabel \\
\hline $\begin{array}{l}\text { WT - Kerjasama } \\
\text { Tim }\end{array}$ & 0.923 & Reliabel \\
\hline $\begin{array}{l}\text { MS - Dukungan } \\
\text { Menejemen }\end{array}$ & 0.923 & Reliabel \\
\hline $\begin{array}{l}\text { TD - } \\
\text { Pengembangan } \\
\text { /pelatihan karyawan }\end{array}$ & 0.897 & Reliabel \\
\hline $\begin{array}{l}\text { PM - Penilaian } \\
\text { kinerja }\end{array}$ & 0.906 & Reliabel \\
\hline $\begin{array}{l}\text { CR - Kompensasi/ } \\
\text { remunirasi }\end{array}$ & 0.958 & Reliabel \\
\hline $\begin{array}{l}\text { WE - Lingkungan/ } \\
\text { tempat Kerja }\end{array}$ & 0.906 & Reliabel \\
\hline $\begin{array}{l}\text { M - Motivasi } \\
\text { karyawan }\end{array}$ & 0.920 & Reliabel \\
\hline $\begin{array}{l}\text { EE - Keterlibatan } \\
\text { Karyawan }\end{array}$ & 0.892 & Reliabel \\
\hline
\end{tabular}

\section{Model Persamaan Struktur}

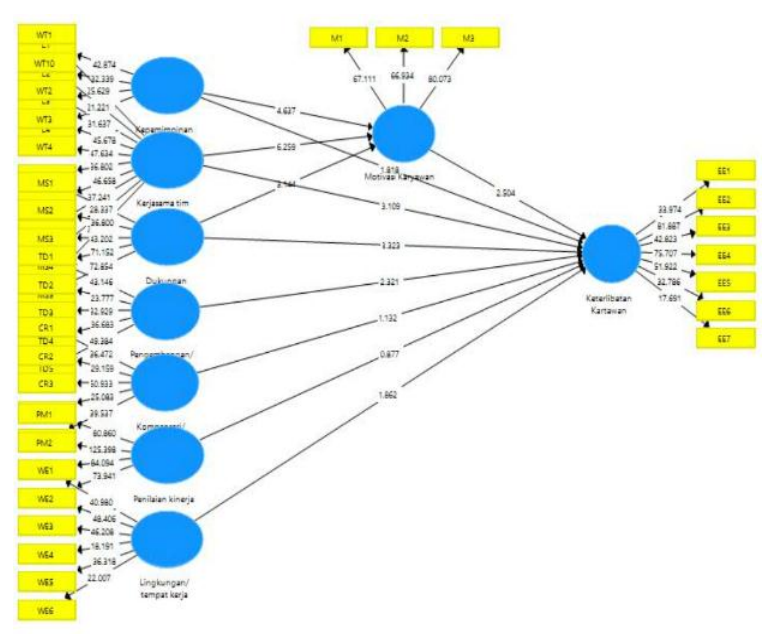

\section{Hasil Uji Pengaruh Langsung dan Tidak Langsung}

Hasil uji pengaruh langsung dan tidak langsung dari hipotesis dapat dilihat pada tabel dibawah.

Tabel 2. Hasil pengujian hipotesis

\begin{tabular}{|l|c|c|l|}
\hline \multicolumn{4}{|c|}{ Pengaruh Langsung } \\
\hline \multicolumn{1}{|c|}{ Variabel } & Statistic & P Values & Kesimpulan \\
\hline $\begin{array}{l}\text { Pengaruh kepemimpinan terhadap } \\
\text { motivasi karyawan) }\end{array}$ & 4.578 & $\mathbf{0}$ & $\begin{array}{l}\text { H1:Berpengaruh } \\
\text { signifikan }\end{array}$ \\
\hline $\begin{array}{l}\text { Pengaruh kerjasama tim terhadap } \\
\text { motivasi karyawan) }\end{array}$ & 6.645 & $\mathbf{0}$ & $\begin{array}{l}\text { H2:Berpengaruh } \\
\text { signifikan }\end{array}$ \\
\hline $\begin{array}{l}\text { Pengaruh dukungan manajemen } \\
\text { terhadap motivasi karyawan }\end{array}$ & 2.949 & $\mathbf{0 . 0 0 3}$ & $\begin{array}{l}\text { H3:Berpengaruh } \\
\text { signifikan }\end{array}$ \\
\hline $\begin{array}{l}\text { Pengaruh pengembangan /pelatihan } \\
\text { karyawan terhadap keterlibatan } \\
\text { karyawan }\end{array}$ & 2.377 & $\mathbf{0 . 0 1 8}$ & $\begin{array}{l}\text { H4:Berpengaruh } \\
\text { signifikan }\end{array}$ \\
\hline $\begin{array}{l}\text { Pengaruh kompensasi/remunirasi } \\
\text { terhadap keterlibatan karyawan }\end{array}$ & 1.127 & $\mathbf{0 . 2 6}$ & $\begin{array}{l}\text { H5:Tidak } \\
\text { berpengaruh } \\
\text { signifikan }\end{array}$ \\
\hline $\begin{array}{l}\text { Pengaruh penilaian kinerja } \\
\text { terhadap keterlibatan karyawan }\end{array}$ & 0.773 & $\mathbf{0 . 4 4}$ & $\begin{array}{l}\text { H6:Tidak } \\
\text { berpengaruh } \\
\text { signifikan }\end{array}$ \\
\hline $\begin{array}{l}\text { Pengaruh lingkungan/ tempat } \\
\text { kerja terhadap keterlibatan } \\
\text { karyawan }\end{array}$ & 2.004 & $\mathbf{0 . 0 4 6}$ & $\begin{array}{l}\text { H7:Berpengaruh } \\
\text { signifikan }\end{array}$ \\
\hline $\begin{array}{l}\text { Pengaruh kepemimpinan } \\
\text { terhadap keterlibatan karyawan }\end{array}$ & 1.845 & $\mathbf{0 . 0 6 6}$ & $\begin{array}{l}\text { H8:Tidak } \\
\text { berpengaruh } \\
\text { signifikan }\end{array}$ \\
\hline $\begin{array}{l}\text { Pengaruh kerjasama tim terhadap } \\
\text { keterlibatan karyawan }\end{array}$ & 3.17 & $\mathbf{0 . 0 0 2}$ & $\begin{array}{l}\text { H9:Berpengaruh } \\
\text { signifikan }\end{array}$ \\
\hline $\begin{array}{l}\text { Pengaruh dukungan manajemen } \\
\text { terhadap keterlibatan karyawan }\end{array}$ & 3.272 & $\mathbf{0 . 0 0 1}$ & $\begin{array}{l}\text { H10:Berpengaruh } \\
\text { signifikan }\end{array}$ \\
\hline $\begin{array}{l}\text { Pengaruh motivasi karyawan } \\
\text { terhadap keterlibatan karyawan }\end{array}$ & 2.443 & $\mathbf{0 . 0 1 5}$ & $\begin{array}{l}\text { H11:Berpengaruh } \\
\text { signifikan }\end{array}$ \\
\hline $\begin{array}{l}\text { Pengaruh motivasi dalam } \\
\text { memediasi hubungan } \\
\text { kepemimpinan terhadap } \\
\text { keterlibatan karyawan }\end{array}$ & $\mathbf{2}$. & $\begin{array}{l}\text { H12:Motivasi } \\
\text { berpengaruh } \\
\text { sebagai full } \\
\text { mediasi }\end{array}$ \\
\hline $\begin{array}{l}\text { Pengaruh motivasi dalam } \\
\text { memediasi hubungan kerjasama tim } \\
\text { terhadap keterlibatan karyawan }\end{array}$ & 2.385 & $\mathbf{0 . 0 1 7}$ & $\begin{array}{l}\text { H13: Motivasi } \\
\text { berpengaruh } \\
\text { sebagai partial } \\
\text { mediasi }\end{array}$ \\
\hline $\begin{array}{l}\text { Pengaruh motivasi dalam } \\
\text { memediasi dukungan manajemen } \\
\text { tim terhadap keterlibatan } \\
\text { karyawan }\end{array}$ & $\begin{array}{l}\text { H14: Motivasi } \\
\text { berpengaruh } \\
\text { sebagai partial } \\
\text { mediasi }\end{array}$ \\
\hline
\end{tabular}




\section{SIMPULAN}

Hasil dari data penelitian menunjukkan bahwa kepemimpinanan, pengembangan /pelatihan karyawan berpengaruh signifikan terhadap keterlibatan karyawan. Hal tersebut memberikan arti bahwa kepengembangan/pelatihan karyawan menjadi suatu hal yang penting terhadap keterlibatan karyawan. Peneliti juga menyimpulkan bahwa motivasi kerja merupakan sebagai mediasi sebagian ketika dukungan Manajemen jika dihubungkan secara tidak langsung terhadap keterlibatan karyawan.

\section{UCAPAN TERIMA KASIH}

Dalam kesempatan ini penulis mengucapkan terima kasih kepada prodi manajemen UIB yang telah memberikan kesempatan dalam menghubungkan penulis dengan pengelolah Journal of Business Management and Hospitality serta disampaikan juga ucapan terima kepada responden dan perusahaan yang mendukung dalam penelitian ini.

\section{DAFTAR PUSTAKA}

Anita, J. (2014). Determinants of employee engagement and their impact on employee performance. International Journal of Productivity and Performance Management, Vol. 63 Issue: 3, pp.308-323.

Ajayi et al. (2017). Stimulating employee ambidexterity and employee engagement in SMEs. Management Decision, Vol. 55 Iss 4 pp.

Akther, S., \& Uddin, M.K. (2016). Employee engagement: An empirical study on telecomiIndustry in Bangladesh, Human Resource
Management Research 2016, 6 (1): 15-22.

Asuka et al. (2017). Job crafting, work engagement, and psychological distress among Japanese employees: a cross-sectional study. Sakuraya et al. BioPsychoSocial Medicine (2017), 11:6.

Brad et al. (2016). Co-workers with benefits: the influence of commitment uncertainty and status on employee engagement in romantic workplace relationships. Journal of Management Development, Vol. 35 Iss 3 pp.

Bulkapuram et al. (2015). Employee engagement and its relation to hospital performance in a tertiary care teaching hospital. Journal of Hospital Administration, 2015, Vol. 4, No. 1.

Caulfield, J. L., \& Senger, A. 2017. Perception is reality: change leadership and work engagement. Leadership \& Organization Development Journal, https://doi.org/10.1108/LODJ-072016-0166.

Chaurasia, S., \& Shukla, A. (2013). The influence of leader-member exchange relations on employee engagement and work role performance. International Journal of Organization Theory \& Behavior, Vol. 16 Issue: 4, pp.465493.

Choo et al. (2013). Organizational practices and employee engagement: a case of Malaysia electronics manufacturing firms. Business Strategy Series, Vol. 14 No. 1 2013, pp. 3-10.

Dajani, M.A.Z. (2015). The Impact of employee engagement on job performance and organisational commitment in the Egyptian 
banking sector, Journal of Business and Management Sciences, 2015, Vol. 3, No. 5, 138-147.

Danish et al. (2014). Determinants of employee engagement in service sector of Pakistan. Universal Journal of Management, 2(2): 6471, 2014.

Darolia, et al. (2010). Perceived organizational support, work motivation, and organizational commitment as determinants of job performance, Journal of the Indian Academy of Applied Psychology, Vol.36, No.1, 69-78.

Davies et al. (2017). When employer brand image aids employee satisfaction and engagement. Journal of Organizational Effectiveness: People and Performance, https://doi.org/10.1108/JOEPP-032017-0028

Deanne et al. (2012). Work engagement and machiavellianism in the ethical leadership process. J Bus Ethics (2012), 107:35-47.

Demirtas, O. (2013). Ethical leadership influence at organizations: Evidence from the field, J Bus Ethics (2015), 126:273-284.

Ehambaranathan et al. (2014). The recent challenges of globalization and the role of employee engagement - The case of Vietnam, International Journal of Human Resource Studies ISSN, 2162-3058 2014, Vol. 5, No. 1.

Engelbrecht et al. (2017). Integrity, leadership of ethics, trust and work engagement. Leadership \& Organization Development Journal, Vol. 38 Iss 3 pp.

Ganesan et al. (2017). Determinants of employee engagement in the
Malaysian health care industry. World Applied Sciences Journal, 35 (10): 2180-2186, 2017.

Ghadi et al. (2013). Transformational leadership and work engagement. Leadership \& Organization Development Journal, Vol. 34 Iss 6 pp. $532-550$.

Gillet et al. (2013). Perceived organizational support, motivation, and engagement among police officers. Professional Psychology: Research and Practice, Vol. 44, No. 1, 46-55.

Gupta, M. (2015). Corporate social responsibility, Employee-company identification, and organizational commitment: Mediation by employee engagement, DOI 10.1007/s 12144-015-9389-8.

Hansen et al. 2014. How interpersonal leadership relates to employee engagement. Journal of Managerial Psychology, Vol. 29 Iss 8, pp. 953972.

Hong et al. (2017). The role of person-job fit in the relationship between transformational leadership and job engagement. Journal of Managerial Psychology.

Hu, J., \& Liden, R.C. (2012). Making a difference in the teamwork: Linking team prosocial motivation to team processes and effectiveness. Academy of Management Journal. Vol. 58, No. 4.

Ibrahim, M., \& Falasi, S.A. (2014). Employee loyalty and engagement in UAE public sector. Employee Relations, Vol. 36 Iss 5 pp. 562 582.

Johari et al. (2013). Fostering employee engagement through human resource practices, A case of manufacturing firms in Malaysia. 
Jurnal Pengurusan 38 (2013) 1526.

Kahn, W.A. (1990). Psychological conditions of personal engagement and disengagement at work. Academy of Management Journal, Vol. 33 No. 4, pp. 692-724.

Kipyegon, J.S., \& Mokaya S.O. (2014). Determinants of employee engagement in the banking industry in Kenya; Case of cooperative bank, Journal of Human Resources Management and Labor Studies, Vol. 2, No. 2, p. 187-200.

Korzynski, P. (2015). Online networking and employee engagement: What current leaders do?. Journal of Managerial Psychology, Vol. 30 Iss $5 \mathrm{pp}$.

Kumar, S., \& Vishal G. (2012). Impact of performance appraisal justice on employee engagement: A study of Indian professionals. Employee Relations, Vol. 35 Issue 1, p. 61-78.

Kumar, S., \& Mehrzi, N. (2016). Competing through employee engagement: a proposed framework, International Journal of Productivity and Performance Management, Vol. 65 Issue: 6, pp.831-843.

Kiersch et al. 2014. How interpersonal leadership relates to employee engagement. Journal of Managerial Psychology, Vol. 29 Iss 8 pp. 953 972.

Marthandan, G., \& Haruna, A.Y. (2017). Foundational competencies for enhancing work engagement in SMEs Malaysia. Journal of Workplace Learning, Vol. 29 Issue: 3, pp.165-184.

Mun et al. (2013). Employee engagement: A study from the private sector in Malaysia. Human Resource
Management Research 2013, 3(1): 43-48.

Murrer, I., \& Farndale, E. (2015). Job resources and employee engagement: a cross-national study. Journal of Managerial Psychology, Vol. 30 Iss 5 pp. 610 - 626.

Naile, I., \& Selesho, J.M. (2014). The role of leadership in employee motivation. Mediterranean Journal of Social Sciences, Vol 5 No 3.

Nazir, O., \& Islam, J.U. (2017). Enhancing organizational commitment and employee performance through employee engagement: An empirical check. South Asian Journal of Business Studies, Vol. 6 Issue: 1, pp.98-114.

Nasomboon, B. (2014). The relationship among leadership commitment, organizational performance, and employee engagement. International Business Research; Vol. 7, No. 9; 2014.

Park, S.M., \& Ugaddan, R.G. (2017). Quality of leadership and public service motivation: A social exchange perspective on employee engagement. International Journal of Public Sector Management, Vol. 30 Issue: 3, pp.270-285.

Piyali et al. (2014). Organizational justice and employee engagement. Exploring the linkage in public sector banks in India, Personnel Review, Vol. 43 No. 4, 2014 pp. 628-652.

Popli, S., \& Rizvi, I.A. (2017). Leadership style and service orientation: the catalytic role of employee engagement. Journal of Service Theory and Practice, Vol. 27 Iss 1 pp.

Popli, S., \& Rizvi, I.A. (2015). Exploring the relationship between service 
orientation, employee engagement and perceived leadership style: a study of managers in the private service sector organizations in India. Journal of Services Marketing, Vol. 29 Iss 1 pp. 59 70.

Prabhakar, G.V., \& Ram, P. (2011). The role of employee engagement in work-related outcomes. Interdisciplinary Journal of Research in Business, Vol. 1, Issue. 3, March 2011(pp.47-61).

Rana et al. (2014). A theoretical model of the antecedents and outcomes of employee engagement. Journal of Workplace Learning, Vol. 26 Iss 3/4 pp. $249-266$.

Rahbi et al. (2017). The effects of leadership styles on team motivation. Academy of Strategic Management Journal, Volume 16, Issue 2, 2017.

Raju, R.S., \& Kassa, A.G. (2015). Investigating the relationship between corporate entrepreneurship and employee engagement. Journal of Entrepreneurship in Emerging Economies, Vol. 7 Iss 2, pp. $148-$ 167.

Rehman et al. (2016). The impact of extrinsic and intrinsic motivation on employee's engagement: An empirical study of health care sector of Peshawar, Pakistan, ISSN 2521 5337.

Song et al. (2014). Team performance in learning organizations: mediating effect of employee engagement. The Learning Organization, Vol. 21 Iss 5 pp. $290-309$.

Tanyu et al. (2014). Do follower characteristics moderate leadership and employee engagement?. Journal of Global Responsibility, Vol. 5 Iss 2 pp. $269-288$.
Tanyu et al. (2014). The relationship between leadership paradigms and employee engagement. Journal of Global Responsibility, Vol. 5 Iss 1 pp. $4-21$.

Tomlinson, G. (2010). Building a culture of high employee engagement. Strategic HR review, Vol. 9 Iss 3 pp. $25-31$.

Tsourvakas, G. \& Yfantidou, I. (2018). Corporate social responsibility influences employee engagement. Social Responsibility Journal, https://doi.org/10.1108/SRJ-092016-0153.

Sahu et al. (2017). Transformational leadership and turnover: Mediating effects of employee engagement, employer branding, and psychological attachment. Leadership \& Organization Development Journal, https://doi.org/10.1108/LODJ-122014-0243

Sugiyono. (2014). Metode penelitian kuantitatif, kualitatif, dan kombinasi (mixed methods). Yogyakarta: Alfabeta.

$\mathrm{Xu}$ et al. (2017). Leader psychological capital and employee work engagement: The roles of employee psychological capital and team collectivism. Leadership \& Organization Development Journal. Vol. 38 Iss 7 pp. 927-945.

Xu, J., \& Thomas, C. (2011). How can leaders achieve high employee engagement?. Leadership \& Organization Development Journal, Vol. 32 Issue, p. 399-416.

Zalk, M.V., \& Khoreva, V. (2016). Antecedents of work engagement among high potential employees. 
Journal of Global Business and Management Review Vol. 1 No. 2, Desember 2019

e-ISSN: 2685-3426

Career Development International, Vol. 21 Iss 5 pp.

Zhu et al. (2016). Relationships between work team climate, individual motivation, and creativity. Journal of Management, DOI: 10.1177/0149206316638161. 